\title{
The effects of a high-fat, high-cholesterol diet on markers of uterine contractility during parturition in the rat
}

\author{
M J Elmes, D S-Y Tan, Z Cheng ${ }^{1}$, D C Wathes ${ }^{1}$ and S McMullen \\ Division of Nutritional Sciences, School of Biosciences, University of Nottingham, Sutton Bonington Campus, \\ Loughborough, Leicestershire LE12 5RD, UK and ${ }^{1}$ Reproduction and Development Group, Royal Veterinary College, \\ Potters Bar, Hertfordshire AL9 7TA, UK
}

Correspondence should be addressed to MJ Elmes; Email: matthew.elmes@nottingham.ac.uk

\begin{abstract}
Increasing levels of obesity within women of reproductive age is a major concern in the UK. Approximately, $13 \%$ of women aged $<30$ and $22 \%$ of 31- to 40-year-old women are obese. Obesity increases complications during pregnancy and the risk of caesarean section due to prolonged labour and poor uterine activity. The aim was to investigate whether a high-fat, high-cholesterol (HFHC) diet decreases markers of uterine contractility during parturition in the rat. Female Wistar rats were fed control (CON, $n=10)$ or $\mathrm{HFHC}(n=10)$ diets for 6 weeks. Animals were mated and, once pregnant, maintained on their diet throughout gestation. On gestational day 19, rats were monitored continuously and killed at the onset of parturition. Body and fat depot weights were recorded. Myometrial tissue was analysed for cholesterol (CHOL), triglycerides (TAG), and expression of the contractile associated proteins gap junction protein alpha 1 (GJA1; also known as connexin-43, CX-43), prostaglandin-endoperoxide synthase 2 (PTGS2; also known as cyclo-oxygenase-2, COX-2) and caveolin-1 (CAV1) and maternal plasma for prostaglandin $F_{2 \alpha}\left(P F_{2 \alpha}\right)$ and progesterone. HFHC fed rats gained greater weight than CON $(\boldsymbol{P}<\mathbf{0 . 0 0 3})$ with significant increases in peri-renal fat $(\boldsymbol{P}<0.01)$. The HFHC diet increased plasma CHOL, TAG and progesterone, but decreased $\mathrm{PGF}_{2 \alpha}$ versus $\mathrm{CON}(\boldsymbol{P}<\mathbf{0 . 0 1}, \boldsymbol{P}<0.01, P=0.05$ and $\boldsymbol{P}<0.02$ respectively). Total $\mathrm{CHOL}$ and TAG levels of uterine tissue were similar. However, HFHC fed rats showed significant increases in PTGS2 $(P<0.037)$, but decreases in GJA1 and CAV1 $(P=0.059)$. In conclusion, a HFHC diet significantly increases body weight and alters lipid profiles that correlate with decreases in key markers of uterine contractility. Further work is required to ascertain whether these changes have adverse effects on uterine activity.

Reproduction (2011) 141 283-290
\end{abstract}

\section{Introduction}

Obesity is a major public health concern, and its prevalence in women of reproductive age is increasing globally (WHO 2000). Currently, $13 \%$ of 21 - to 30 -yearold women and $22 \%$ of 31 - to 40 -year-old women in the UK are obese, with figures estimated to rise to 30 and $47 \%$ respectively by 2050 (FORESIGHT 2001). Obese women have a significantly higher risk of developing complications during pregnancy than those with a normal body mass index, and are at an increased risk of undergoing emergency caesarean section (Crane et al. 1997, Loverro et al. 2001, Cedergren 2004, Weiss et al. 2004) due to poor uterine activity and prolonged labour (Zhang et al. 2007).

Obesity correlates positively with plasma cholesterol (CHOL) concentrations (Gostynski et al. 2004), and raised serum $\mathrm{CHOL}$ in obese pregnant women (Ramsay et al. 2002) has been observed to play a key role in smooth muscle contraction (Babiychuk et al. 2004, Smith et al. 2005). Ex vivo manipulation of myometrial $\mathrm{CHOL}$ content reveals that decreasing and increasing $\mathrm{CHOL}$ increases and decreases the strength of myometrial contractions respectively, suggesting that high circulatory $\mathrm{CHOL}$ seen in many obese women could impair uterine activity during labour (Smith et al. 2005).

Uterine contractile activity is regulated by the key proteins caveolin-1 (CAV1), gap junction protein alpha 1 (GJA1; also known as connexin-43, CX-43) and prostaglandin-endoperoxide synthase 2 (PTGS2; also known as cyclooxygenase-2, COX-2). CAV1 is the critical structural component of caveolae (Okamoto et al. 1998), which are omega-shaped CHOL-rich invaginations of cell membranes that act as platforms for the coding of intracellular signals (Schlegel et al. 1998, Shaul \& Anderson 1998). Although three different isoforms exist (CAV1-3; Okamoto et al. 1998), CAV1 controls activity of transduction pathways as Cav1 knockout mice exhibit impaired smooth muscle (aortic ring) vascular relaxation (Drab et al. 2001), and $\mathrm{CHOL}$ extraction reduces caveolae number increasing contractility of both human and rodent myometrium (Noble et al. 2006). High CHOL concentrations may increase caveolae number and CAV1 expression of 

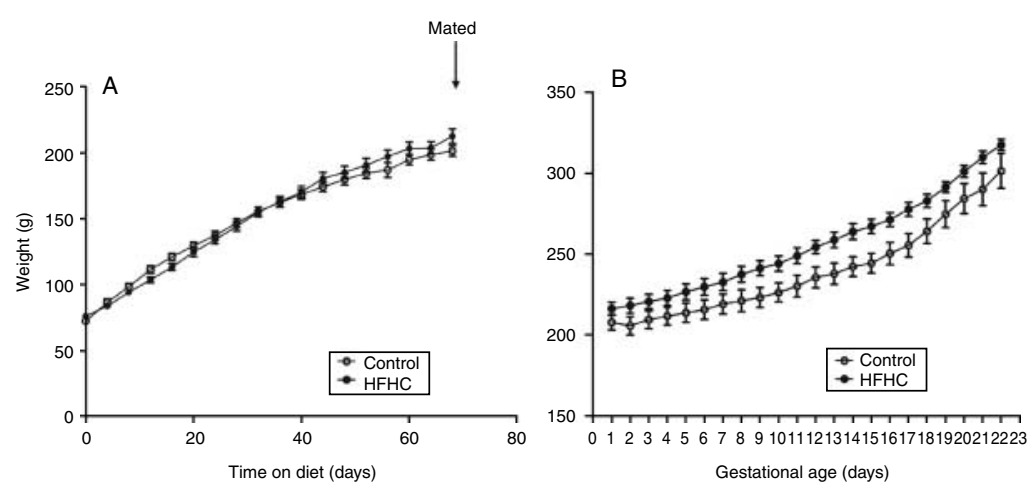

Figure 1 Body weight changes 6 weeks before mating (A) and during pregnancy (B) in rats fed either a control $(n=10)$ or HFHC $(n=10)$ diet. Values are means with S.E.M. represented by vertical bars. Weight gain prior to pregnancy was not dissimilar between dietary groups, however weight gain during pregnancy was significantly higher in HFHC fed animals $(P<0.003)$. myometrial tissue, and may be a possible mechanism through which obesity leads to prolonged labour.

During labour, the uterus is primed to contract in response to stimuli through coordinated up-regulation of the contractile associated proteins (CAPS) GJA1 and PTGS2 (Challis \& Lye 1994). GJA1 is the major myometrial gap junction that facilitates intracellular propagation of electrical impulses (Willecke et al. 2002) and synchronised myometrial contractions. As a consequence, GJA1 is up-regulated following the onset of labour and during delivery (Garfield et al. 1977, 1995, Chow \& Lye 1994, Orsino et al. 1996). GJA1 plays a key role in parturition as its myometrial loss leads to defects in physiological coordination of uterine contractions, and labour is subsequently prolonged (Cluff et al. 2006, Doring et al. 2006). PTGS2 is responsible for the synthesis of the prostaglandins, $\mathrm{PGF}_{2 \alpha}$ and $\mathrm{PGE}_{2}$, which regulate uterine activity during pregnancy and parturition (Zuo et al. 1994). $\mathrm{PGE}_{2}$ causes uterine relaxation (Lopez Bernal et al. 1993), whereas $\mathrm{PGF}_{2 \alpha}$ stimulates the myometrial contractions that expel the foetus during labour (Challis et al. 1997). Uterine PTGS2 expression rises during late gestation but increases significantly with the onset of labour (Dong et al. 1996), and selective inhibition blocks PG production and delays induced labour in sheep (Scott et al. 2001) and mice (Gross et al. 2000).

Although current evidence suggests that myometrial contractility during labour may be adversely affected by obesity via CHOL-mediated mechanisms, no study to date has investigated this directly in an in vivo model. Therefore, the purpose of the present study was to utilise an animal model to test the hypothesis that a high-fat, high-cholesterol (HFHC) diet would lead to adverse lipid profiles and decrease expression of key markers of uterine contractility during parturition in the rat.

\section{Results}

\section{Body and fat depot weights}

Rats were fed either a control (CON) chow diet or a HFHC diet for 6 weeks prior to mating and throughout pregnancy. Feeding the HFHC diet to Wistar rat dams for 6 weeks prior to mating did not increase weight gain and therefore body weight at mating significantly when compared with controls (Fig. 1A and Table 1). However, pregnant rats maintained on the HFHC diet throughout gestation gained more weight than rats fed a CON diet, leading to a significant difference in body weight at the end of pregnancy (Fig. 1B and Table 1). Weighing of different fat depots revealed that only renal fat was affected by diet, with a significant weight increase in the HFHC fed rat dams (See Table 1).

\section{Litter size and weight}

Both groups of rats commenced delivery at a similar stage of gestation: controls took $22.2 \pm 0.16$ days and HFHC fed rats took $22.5 \pm 0.23$ days respectively. Litter size was not affected by maternal diet, and similarly average pup weights and total litter weights were not significantly different between pregnant rats fed either a CON or diet a HFHC diet (see Table 1).

\section{Lipid profiles}

Determination of total $\mathrm{CHOL}$ and triglyceride (TAG) concentration in the maternal plasma and uterine tissue from laboratory chow and HFHC fed rat dams produced contrasting results (Fig. 2). Circulating plasma total

Table 1 Measurements of body weight, litter size and weight and fat pad weights in control rats and those fed a high-fat, high-cholesterol (HFHC) $\operatorname{diet}^{\mathrm{a}}$.

\begin{tabular}{lrrr}
\hline & Control $(n=8)$ & HFHC $(n=7)$ & P value \\
\hline $\begin{array}{l}\text { Pre-pregnancy weight } \\
\quad \text { gain (g) }\end{array}$ & $132.67 \pm 4.11$ & $142.09 \pm 4.79$ & 0.403 \\
End of pregnancy & $302.05 \pm 6.21$ & $321.37 \pm 3.04$ & 0.054 \\
$\quad$ weight (g) & $11.13 \pm 1.09$ & $10.14 \pm 0.94$ & 0.513 \\
Litter size ( $n)$ & $5.48 \pm 0.15$ & $5.41 \pm 0.12$ & 0.717 \\
Average pup weight (g) & $61.23 \pm 5.70$ & $54.46 \pm 4.54$ & 0.379 \\
Total litter weight (g) & $2.77 \pm 0.26$ & $3.93 \pm 0.35$ & $<0.02$ \\
Renal fat (g) & $7.15 \pm 0.76$ & $8.11 \pm 0.71$ & 0.41 \\
Gonadal fat (g) & $0.93 \pm 0.26$ & $0.86 \pm 0.17$ & 0.829 \\
Intrascapular fat (g) & & & \\
\hline
\end{tabular}

${ }^{a}$ Except for the pre-pregnancy weight gain, all other measurements were taken immediately after birth of the first pup. 


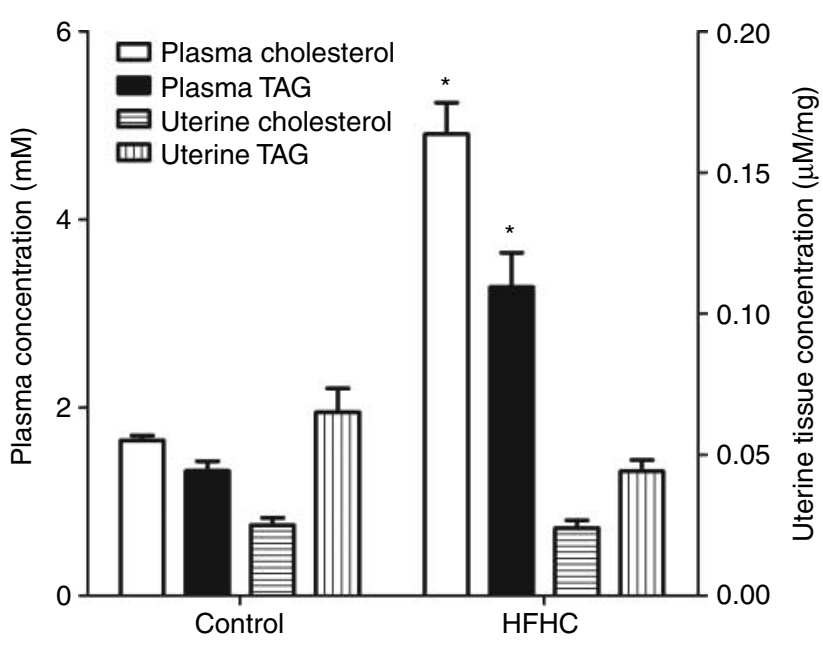

Figure 2 The effects of feeding either a control $(n=8)$ or $\mathrm{HFHC}(n=7)$ diet for 6 weeks prior to and during pregnancy on the concentrations of total cholesterol and TAG within maternal plasma and uterine tissue during parturition in the rat. Values are means with S.E.M. represented by vertical bars. Data were analysed by one-way ANOVA and significant differences between control and HFHC rats were at the $P<0.005$ level $(*)$.

$\mathrm{CHOL}$ and TAG concentrations were almost three times higher in HFHC fed rat dams compared with controls (both $P<0.001$ ). Uterine tissue levels of $\mathrm{CHOL}$ and TAG did not, however, differ between the two dietary groups.

\section{Uterine expression of CAPs}

Western blot analysis of GJA1, PTGS2 and CAV1 provided evidence that a HFHC diet can significantly alter the uterine expression of CAPs during parturition (Fig. 3). Rat dams fed the HFHC diet had significantly a lower expression of GJA1 and CAV1 (both at the $P<0.059$ level), but a higher expression of PTGS2 in comparison to controls $(P<0.037)$.

\section{Maternal plasma $\mathbf{P G F}_{2 \alpha}$}

After identifying that the HFHC diet caused a significant increase in uterine expression of PTGS2 during established labour, it was important to elucidate whether this increase would result in changes in $\mathrm{PGF}_{2 \alpha}$, which regulate myometrial contractions and help to expel the foetus during labour. Analysis of maternal plasma for $\mathrm{PGF}_{2 \alpha}$ through RIA revealed that the feeding of a HFHC diet significantly reduced circulatory levels of $\mathrm{PGF}_{2 \alpha}$ from $0.16 \pm 0.022 \mathrm{ng} / \mathrm{ml}$ (observed in controls) to $0.086 \pm 0.023 \mathrm{ng} / \mathrm{ml} ; P<0.02$ (Fig. 4a).

\section{Maternal plasma progesterone}

With data already establishing that a HFHC diet decreases myometrial expression of key CAPs during labour, we wanted to determine whether maternal progesterone levels that can influence the expression of
CAPs within the myometrium are altered by the HFHC diet. Analysis of maternal plasma for progesterone provided evidence that a HFHC diet fed prior to and during pregnancy was associated with dams starting labour with a significantly higher progesterone level of $33.9 \pm 2.9 \mathrm{ng} / \mathrm{ml}$ compared with $27.3 \pm 2.4 \mathrm{ng} / \mathrm{ml}$, observed in controls; $P=0.05$ (Fig. 4b).

\section{Discussion}

This study was the first to utilise a rat model to assess the effects of a HFHC diet on maternal lipid profiles and markers of uterine activity during parturition. The aim was to investigate whether dietary increases in lipid profiles would down-regulate key CAPs during labour in the rat, providing a possible mechanism behind the dysfunctional labour and poor myometrial activity commonly observed in obese women (Crane et al. 1997, Loverro et al. 2001, Cedergren 2004, Weiss et al. 2004, Zhang et al. 2007). Significant elevations in serum $\mathrm{CHOL}$ and TAGs are a normal occurrence during pregnancy (Piechota \& Staszewski 1992, Toescu et al. 2004), but feeding a HFHC diet to rats 6 weeks prior to and during pregnancy significantly increased the circulatory levels of $\mathrm{CHOL}$ and TAGs when compared with
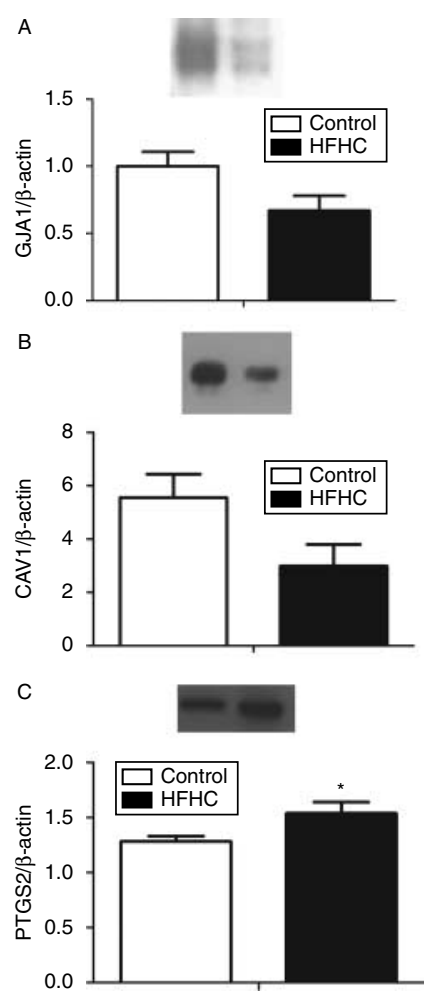

Figure 3 The effects of feeding a control $(n=8)$ or $\operatorname{HFHC~}(n=7)$ diet for 6 weeks prior to and during pregnancy on uterine protein expression of contractile associated proteins (A), CAV1 (B) and PTGS2 (C) during parturition in the rat. Following densitometry, data were analysed by one-way ANOVA and $P$ values for CAV1 and PTGS2 between control and HFHC fed animals were $P<0.059, P<0.059$ and ${ }^{*} P<0.037$ respectively. 


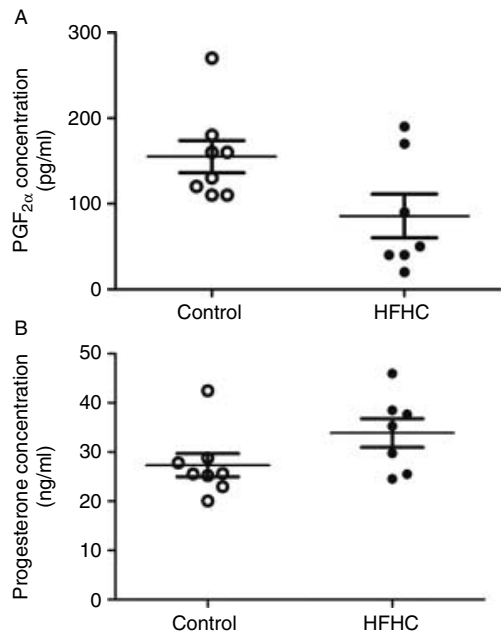

Figure 4 The effects of feeding a control $(n=8)$ or HFHC $(n=7)$ diet for 6 weeks prior to and during pregnancy on the circulatory levels of (a) $\mathrm{PGF}_{2 \alpha}$ and (b) progesterone. Values are means with S.E.M. represented by vertical bars. Data were analysed by one-way ANOVA and significant differences between control and $\mathrm{HFHC}$ rats were at the $P<0.02$ level $\left(\mathrm{PGF}_{2 \alpha}\right)$ and $P=0.05$ (progesterone).

controls, mirroring the raised serum level of $\mathrm{CHOL}$ and TAGs observed in obese pregnant women (Ramsay et al. 2002). In contrast, and despite the increased circulating levels of $\mathrm{CHOL}$ and TAGs, feeding rats a HFHC diet did not increase incorporation of total $\mathrm{CHOL}$ levels within uterine tissue.

Previous studies investigating the effects of $\mathrm{CHOL}$ on uterine activity only manipulated tissue $\mathrm{CHOL}$ concentrations in an ex vivo setting, where myometrial strips were derived either from caesarean section biopsies in women (Zhang et al. 2007) or dissected from pregnant rats (Smith et al. 2005). Both studies provide evidence that $\mathrm{CHOL}$ content within myometrial tissue is important for normal uterine function during pregnancy. $\mathrm{CHOL}$ enrichment was inhibitory to both spontaneous and oxytocin-stimulated contractile force of the myometrium, and reversed following $\mathrm{CHOL}$ depletion. But an important omission that remains to be determined is whether uterine tissue from obese pregnant women who exhibit poor uterine activity during labour actually has increased incorporation of $\mathrm{CHOL}$ within their plasma membranes compared with women undergoing routine delivery. Within our model, the raised circulating $\mathrm{CHOL}$ concentrations induced by a HFHC diet were not reflected in uterine tissue. It is, however, possible that the $\mathrm{CHOL}$ could be in different pools within the cells from rats fed the HFHC diet or CON diet.

Despite the HFHC diet having no effect on the uterine tissue concentration of $\mathrm{CHOL}$ and TAGs during labour, significant differences in expression of key CAPs were evident. Feeding rats a HFHC diet decreased uterine expression of CAV1 and GJA1, but increased expression of PTGS2 significantly. Decreased expression of myometrial GJA1 during labour agrees with our original hypothesis, but the respective increase and decrease in PTGS2 and CAV1 expression were unexpected. Caveolae and their structural proteins CAVs (Okamoto et al. 1998) are extensive in myometrial smooth muscle cells increasing its surface area by almost 75\% (Somlyo 1985). CAVs act as a scaffold to congregate multiple proteins involved in calcium signalling and $\mathrm{CON}$ of smooth muscle contractions, including calcium channels, calcium-binding proteins, calcium pumps (Darby et al. 2000) and calcium-sensitive potassium channels (Brainard et al. 2005). The calcium-sensitive potassium channel provides a strong repolarising current to buffer cell excitation in response to excitatory cell signals (Jackson 2000), and inhibition of this channel pharmacologically during late pregnancy induces myometrial cell depolarisation and enhanced uterine contraction (Anwer et al. 1993). Interestingly, uterine extraction of $\mathrm{CHOL}$ reduces caveolae number and CAV1 expression, resulting in increased contractility of human and rodent myometrium (Riley et al. 2003, Noble et al. 2006). This finding implies that decreased uterine expression of CAV1 following a HFHC diet in the context of this study may act to increase myometrial contractile activity during labour, suggesting that CAV1 expression is not adversely affected by the HFHC diet as hypothesised.

The HFHC diet was also associated with a reduced expression of the gap junction protein GJA1 within labouring uterine tissue. GJA1 gap junctions are specialised channels that allow direct intracellular transfer between coupled cells, thereby facilitating electrical communication and synchronous contractile activity (Willecke et al. 2002). GJA1 is expressed in extremely low levels in the non-pregnant uterus, but is increased significantly in abundance during parturition (Chow \& Lye 1994, Orsino et al. 1996, Ou et al. 1997). GJA1 plays a key role in parturition, as extensive, but not full, loss of protein leads to uncoordinated contractile function of the murine uterus and prolonged labour (Doring et al. 2006). Similar findings are observed in women experiencing prolonged labour, as they exhibit significantly lower expression of GJA1 than women with routine deliveries. Mechanical stretch of the uterus is another key regulator of myometrial contractile activity. Two key studies reported increases in gap junction number following distension of the non-pregnant rat uterus with an intrauterine balloon (Wathes \& Porter 1982, Manabe et al. 1985). Furthermore, uterine distension was shown to be a requirement for full expression of GJA1 and synchronous uterine contractility during labour (Garfield et al. 1995, Ou et al. 1997). Rapid foetal growth that occurs during the final stages of pregnancy could be the stretch-induced stimulus that enhances uterine expression of GJA1. Importantly, offspring weights and litter size (Table 1) at birth did not differ between rats fed the CON or HFHC diets, providing evidence that decreased uterine expression of GJA1 during labour in HFHC fed animals was not due to 
differences in stretch-induced stimuli. The current findings suggest that exposure to a HFHC diet decreases uterine expression of GJA1, and may thus lead to uncoordinated uterine contractions and prolonged labour. Although the timing of delivery for the first pup was similar between CON and HFHC fed rats (both started to deliver at 22 days), this does not indicate whether uterine contractile strength or length of labour for delivery of whole litters was adversely affected.

PTGS2-derived $\mathrm{PGE}_{2}$ and $\mathrm{PGF}_{2 \alpha}$ increase with the onset of labour (Zuo et al. 1994, Dong et al. 1996, Lye 1996), and are responsible for uterine relaxation (Lopez Bernal et al. 1993) and activation of contractile machinery respectively. Inhibition of PTGS2 blocks basal PG production and delays induced premature labour in sheep (Poore et al. 1999) and mice (Gross et al. 2000). The current finding that a HFHC diet increased PTGS2 expression in labouring uterine tissue was unexpected. However, recent research has provided evidence that saturated fatty acids induce expression of PTGS2 in macrophage cells (Lee et al. 2001), which infiltrate the myometrium and cervix with the onset of labour (Thomson et al. 1999, Osman et al. 2003). The HFHC diet fed to rats prior to and during pregnancy is high in saturated fat, and could explain the increased PTGS2 expression in their labouring uterine tissue. Despite this increase, there was no positive correlation with circulatory $\mathrm{PGF}_{2 \alpha}$ concentrations, which were significantly reduced in rat dams fed the CON diet. Lower $\mathrm{PGF}_{2 \alpha}$ concentrations could produce less forceful contractions during labour and could be due to decreased incorporation of unsaturated fatty acids (that are precursors for PG production) into the phospholipid membrane of the uterine tissue. Another possible reason for the discrepancy between PTGS2 expression and plasma $\mathrm{PGF}_{2 \alpha}$ concentration may be that the HFHC diet inhibited PGF synthase (PGFS) activity, which converts $\mathrm{PGH}_{2}$ into $\mathrm{PGF}_{2 \alpha}$.

With CHOL being an important precursor for steroid hormone production that plays key roles in the timing of labour and myometrial expression of CAPs, we determined the maternal plasma concentrations of progesterone between the two dietary groups. Our data revealed that rats exposed to a HFHC diet had significantly higher concentrations of plasma progesterone at labour onset when compared with controls. This associated decreased expression of the myometrial GJA1 with higher maternal progesterone concentrations is consistent with previously published studies. Administration of exogenous progesterone at term in the ewe not only inhibits the expression of myometrial CAPs but also blocks the onset of labour (Lye \& Porter 1978). Furthermore, functional withdrawal of progesterone in the myometrium induces CAP expression and activates myometrial contractile activity (Lye et al. 1998). These data therefore provide some evidence to suggest that the adverse effects of a HFHC diet on myometrial contractile protein expression may be mediated through alterations in steroid synthesis.

In conclusion, a HFHC diet fed prior to and during pregnancy led to significant increases in circulatory $\mathrm{CHOL}, \mathrm{TAG}$ and progesterone concentrations, which were associated with altered expression of CAPs in labouring uterine tissue. Contrary to our original hypotheses, expression of CAV1 and PTGS2 were decreased and increased respectively, which would be expected to increase contractility. In contrast, GJA1 expression and circulatory $\mathrm{PGF}_{2 \alpha}$ concentrations were decreased, which we speculate could adversely affect co-ordination and strength of myometrial contractions during parturition in the rat. Further research is required: firstly, to determine whether these changes in uterine expression of CAPs following a HFHC diet lead to adverse physiological changes in myometrial contractions; secondly, whether these changes occur through key alterations in synthesis of steroid hormones of which $\mathrm{CHOL}$ is the precursor and finally whether the HFHC diet affects the expression and activities of PGFS and PGES.

\section{Materials and Methods}

\section{Animals and experimental design}

Within the animal facilities at the University of Nottingham, twenty virgin Wistar rat dams (Harlan Ltd, Belton, Leics, UK) weighing $\sim 60 \mathrm{~g}$ were pair-housed and randomly assigned to be fed either a CON (standard laboratory chow, B\&K Universal Ltd, Hull, UK, $n=10)$ or a HFHC $(n=10)$ diet for 6 weeks (HFHC diet details in Table 2). Rat dams were then mated naturally with Wistar stud males, and pregnancy was confirmed through the appearance of a semen plug on the cage floor. The pregnant rats were then housed individually and maintained on their CON or HFHC diets throughout gestation until birth at 22 days of gestation. Daily food intake and weight gains were recorded prior to and during pregnancy. At gestational day 20, hourly checks were made for signs of parturition, and following the birth of the first pup, each rat dam was immediately killed by $\mathrm{CO}_{2}$ asphyxiation and cervical dislocation. Maternal blood samples were collected by cardiac puncture and transferred to heparin tubes, centrifuged at

Table 2 Composition of the high-fat, high-cholesterol diet.

\begin{tabular}{lr}
\hline Constituents & $\mathrm{g} / \mathrm{kg}$ \\
\hline Corn oil & 100 \\
Casein & 200 \\
Maize starch & 218 \\
Butter & 295 \\
Sucrose & 100 \\
Cellulose & 50 \\
Vitamin mix & 5 \\
Mineral mix & 20 \\
Methionine & 10 \\
Choline & 2 \\
Cholesterol & 10 \\
\hline
\end{tabular}


$13000 \mathrm{~g}$ at $4{ }^{\circ} \mathrm{C}$ for $10 \mathrm{~min}$, and the plasma was retained for analysis of TAG, $\mathrm{CHOL}$ and $\mathrm{PGF}_{2 \alpha}$. The uterus was dissected; foetuses were removed and separated from their foetal membranes and placentas and killed by destruction of the brain and decapitation. The uterus was immediately split into two horns, snap frozen and stored at $-80{ }^{\circ} \mathrm{C}$ until subsequent analysis of TAG and $\mathrm{CHOL}$ content and expression of the CAPs, GJA1, CAV1 and PTGS2. In addition, renal, gonadal and intrascapular adipose tissue depots were carefully dissected and weighed to the nearest $0.1 \mathrm{mg}$ and snap frozen in liquid nitrogen.

\section{Total CHOL and TAG assays}

Total $\mathrm{CHOL}$ and TAGs in the maternal plasma and uterine tissue were assayed through a commercially bought kit (ThermoTrace, Noble Park, Vic., Australia) according to the manufacturer's instructions. Standard curves ranging from 0 to $5 \mathrm{mM}$ and from 0 to $3.5 \mathrm{mM}$ were produced for $\mathrm{CHOL}$ and TAGs respectively. On a 96-well plate, $200 \mu \mathrm{l}$ of $\mathrm{CHOL}$ or TAG assay reagent was added to $10 \mu \mathrm{l}$ of sample or standard in duplicate, and incubated for $15 \mathrm{~min}$ at $37^{\circ} \mathrm{C}$. The absorbance was then read at $550 \mathrm{~nm}$ (with a reference wavelength of $655 \mathrm{~nm}$ ). The intra-assay coefficient of variation (CV) for plasma $\mathrm{CHOL}$ and TAG was 5.1 and $1 \%$ respectively. Determination of $\mathrm{CHOL}$ and TAG in uterine tissue was achieved following lipid extraction. In a mixture of hexane/ isopropanol $(3: 2 \mathrm{v} / \mathrm{v}), 300 \mathrm{mg}$ of uterine tissue was homogenised for $5 \mathrm{~min}$. The contents were then centrifuged at $2000 \mathrm{~g}$ for $5 \mathrm{~min}$ at $25{ }^{\circ} \mathrm{C}$. The resulting liquid phase was carefully removed and dried under liquid nitrogen for $1 \mathrm{~h}$. The dried extract was then dissolved in $1 \mathrm{ml}$ isopropanol and analysed using the same procedure as above and expressed in $\mu \mathrm{M} / \mathrm{mg}$ tissue. The intra-assay $\mathrm{CV}$ for uterine $\mathrm{CHOL}$ and TAG was 2.5 and $2 \%$ respectively.

\section{Western blot analysis}

For analysis of uterine expression of GJA1, CAV1 and PTGS2, one frozen uterine horn was ground to a powder in liquid nitrogen and homogenised briefly for $30 \mathrm{~s}$ in ice-cold buffer containing $5 \mathrm{mM}$ Tris, $\mathrm{pH} 7.4,2 \mathrm{mM}$ EDTA and protease inhibitor cocktail (Calbiochem, San Diego, CA, USA). Homogenates were then split into three parts for analysis of each protein. Homogenate for PTGS2 underwent centrifugation at $13000 \mathbf{g}$, and both GJA1 and CAV1 were spun at $3500 \mathrm{~g}$ for $15 \mathrm{~min}$ at $4{ }^{\circ} \mathrm{C}$, and the supernatants were extracted. Protein concentrations of each supernatant were determined using the Bio-Rad protein assay system (Bio-Rad) according to the manufacturer's instructions. Samples were standardised to a concentration of $4 \mathrm{mg} / \mathrm{ml}$ with Laemmli's sample buffer (62.5 mM Tris, $\mathrm{pH}$ 6.8, $2 \%$ SDS, $10 \%$ glycerol, $0.02 \%$ bromophenol blue and $150 \mathrm{mM}$ dithiothreitol) and boiled for $3 \mathrm{~min}$ before equal protein quantities of each sample were separated by SDS-PAGE. Proteins were transferred to nitrocellulose membrane (Hybond-C extra, Amersham Bioscience) for probing with antibodies to PTGS2 (Santa Cruz Biotechnology, Inc., Santa Cruz, CA, USA; rabbit polyclonal antibody raised against amino acids $50-111$ of PTGS2 of human origin), GJA1 (Cell Signalling, Danvers, MA, USA; rabbit polyclonal antibody raised against a synthetic peptide corresponding to residues of human GJA1) and CAV1 (Cell Signalling; rabbit $M A B$ raised against a synthetic peptide corresponding to residues near the amino terminus of human CAV1). Membranes were incubated in blocking solution (5\% dried skimmed milk in TBS with 1\% Tween-20) prior to incubation with primary antibodies. HRP secondary antibody conjugated to rabbit IgG was used at a working concentration of 1:5000 (GE Healthcare, Amersham, UK). Bands were developed on high performance chemiluminescence film (Hyperfilm ECL, Amersham) using ECL reagent (GE Healthcare). Densitometric analysis of band intensity was performed using a Bio-Rad Gel Doc XR imaging system and Quantity One $1 \mathrm{D}$ analysis software.

\section{RIA for $P G F_{2 \alpha}$ and progesterone}

The concentration of $\mathrm{PGF}_{2 \alpha}$ and progesterone in maternal plasma was quantified using established RIAs (Wathes et al. 1986, Leung et al. 2001). The tritiated tracers ([5, 6, 8, 9, 11, $\left.12,14,15(\mathrm{n})-{ }^{3} \mathrm{H}\right] \mathrm{PGF}_{2 \alpha}$ and $\left[1,2,6,7,16,17-{ }^{3} \mathrm{H}\right]$ progesterone) were obtained from Amersham International, and standards were supplied by Sigma-Aldrich. The antisera against $\mathrm{PGF}_{2 \alpha}$ and progesterone were kind gifts from $\mathrm{Dr} N \mathrm{~L}$ Poyser (University of Edinburgh, Edinburgh, UK) and Dr M Sauer (Veterinary Laboratory Agency, Weybridge, Surrey, UK) respectively. The concentrations of $\mathrm{PGF}_{2 \alpha}$ and progesterone were calculated using a semi-logarithmic plot. The limit of detection for $\mathrm{PGF}_{2 \alpha}$ was $1 \mathrm{pg} /$ tube with an intra-assay $\mathrm{CV}$ value of $4.7 \%$, and the limit of detection and intra-assay $\mathrm{CV}$ for progesterone were $0.22 \mathrm{ng} / \mathrm{ml}$ and $8.7 \%$ respectively.

\section{Statistical analysis}

All data were analysed using the Statistical Package for Social Science (Version 16; SPSS, Inc., Chicago, IL, USA). The effect of feeding the HFHC diet on measured outcomes was determined through use of one-way ANOVA. All data are expressed as the mean value with S.E.M., and $P<0.05$ was considered as statistically significant.

\section{Declaration of interest}

The authors declare that there is no conflict of interest that could be perceived as prejudicing the impartiality of the research reported.

\section{Funding}

This research did not receive any specific grant from any funding agency in the public, commercial or notfor-profit sector. The Physiological Society funded D S-Y Tan with a Summer Vacation Studentship

\section{Acknowledgements}

The authors acknowledge the expert technical assistance of Mr Richard Plant, Miss Sarah Kirkland and Mrs C Armett. 


\section{References}

Anwer K, Oberti C, Perez GJ, Perez-Reyes N, McDougall JK, Monga M, Sanborn BM, Stefani E \& Toro L 1993 Calcium-activated $\mathrm{K}^{+}$channels as modulators of human myometrial contractile activity. American Journal of Physiology 265 C976-C985.

Babiychuk EB, Smith RD, Burdyga T, Babiychuk VS, Wray S \& Draeger A 2004 Membrane cholesterol regulates smooth muscle phasic contraction. Journal of Membrane Biology 198 95-101. (doi:10.1007/s00232004-0663-1)

Brainard AM, Miller AJ, Martens JR \& England SK 2005 Maxi-K channels localize to caveolae in human myometrium: a role for an actin-channelcaveolin complex in the regulation of myometrial smooth muscle $\mathrm{K}^{+}$ current. American Journal of Physiology. Cell Physiology 289 C49-C57. (doi:10.1152/ajpcell.00399.2004)

Cedergren MI 2004 Maternal morbid obesity and the risk of adverse pregnancy outcome. Obstetrics and Gynecology 103 219-224. (doi:10. 1097/01.AOG.0000107291.46159.00)

Challis JRG \& Lye SJ 1994 Parturition. In The Physiology of Reproduction, vol 2, pp 985-1031. Eds E Knobil \& JD Neill. New York: Raven Press.

Challis JR, Lye SJ \& Gibb W 1997 Prostaglandins and parturition. Annals of the New York Academy of Sciences 828 254-267. (doi:10.1111/ j.1749-6632.1997.tb48546.x)

Chow L \& Lye SJ 1994 Expression of the gap junction protein connexin-43 is increased in the human myometrium toward term and with the onset of labor. American Journal of Obstetrics and Gynecology 170 788-795.

Cluff AH, Bystrom B, Klimaviciute A, Dahlqvist C, Cebers G, Malmstrom A \& Ekman-Ordeberg G 2006 Prolonged labour associated with lower expression of syndecan 3 and connexin 43 in human uterine tissue. Reproductive Biology and Endocrinology 4 24. (doi:10.1186/14777827-4-24)

Crane SS, Wojtowycz MA, Dye TD, Aubry RH \& Artal R 1997 Association between pre-pregnancy obesity and the risk of cesarean delivery. Obstetrics and Gynecology 89 213-216. (doi:10.1016/S0029 7844(96)00449-8)

Darby PJ, Kwan CY \& Daniel EE 2000 Caveolae from canine airway smooth muscle contain the necessary components for a role in $\mathrm{Ca}(2+)$ handling. American Journal of Physiology. Lung Cellular and Molecular Physiology 279 L1226-L1235.

Dong YL, Gangula PR, Fang L \& Yallampalli C 1996 Differential expression of cyclooxygenase- 1 and -2 proteins in rat uterus and cervix during the estrous cycle, pregnancy, labor and in myometrial cells. Prostaglandins 52 13-34. (doi:10.1016/0090-6980(96)00059-7)

Doring B, Shynlova O, Tsui P, Eckardt D, Janssen-Bienhold U, Hofmann F, Feil S, Feil R, Lye SJ \& Willecke K 2006 Ablation of connexin43 in uterine smooth muscle cells of the mouse causes delayed parturition. Journal of Cell Science 119 1715-1722. (doi:10.1242/jcs.02892)

Drab M, Verkade P, Elger M, Kasper M, Lohn M, Lauterbach B, Menne J, Lindschau C, Mende F, Luft FC et al. 2001 Loss of caveolae, vascular dysfunction, and pulmonary defects in caveolin-1 gene-disrupted mice. Science 293 2449-2452. (doi:10.1126/science.1062688)

FORESIGHT 2001 Tackling Obesities: Future Choices - Project Report. London: Government Office for Science.

Garfield RE, Sims S \& Daniel EE 1977 Gap junctions: their presence and necessity in myometrium during parturition. Science 198 958-960. (doi:10.1126/science.929182)

Garfield RE, Ali M, Yallampalli C \& Izumi H 1995 Role of gap junctions and nitric oxide in control of myometrial contractility. Seminars in Perinatology 19 41-51. (doi:10.1016/S0146-0005(95)80046-8)

Gostynski M, Gutzwiller F, Kuulasmaa K, Doring A, Ferrario M, Grafnetter D \& Pajak A 2004 Analysis of the relationship between total cholesterol, age, body mass index among males and females in the WHO MONICA Project. International Journal of Obesity and Related Metabolic Disorders 28 1082-1090. (doi:10.1038/sj.ijo. 0802714)

Gross G, Imamura T, Vogt SK, Wozniak DF, Nelson DM, Sadovsky Y \& Muglia LJ 2000 Inhibition of cyclooxygenase-2 prevents inflammationmediated preterm labor in the mouse. American Journal of Physiology. Regulatory, Integrative and Comparative Physiology 278 R1415-R1423.

Jackson WF 2000 lon channels and vascular tone. Hypertension 35 $173-178$.
Lee JY, Sohn KH, Rhee SH \& Hwang D 2001 Saturated fatty acids, but not unsaturated fatty acids, induce the expression of cyclooxygenase-2 mediated through Toll-like receptor 4. Journal of Biological Chemistry 276 16683-16689. (doi:10.1074/jbc.M011695200)

Leung ST, Cheng Z, Sheldrick EL, Derecka K, Derecka K, Flint AP \& Wathes DC 2001 The effects of lipopolysaccharide and interleukins1alpha, -2 and -6 on oxytocin receptor expression and prostaglandin production in bovine endometrium. Journal of Endocrinology 168 497-508. (doi:10.1677/joe.0.1680497)

Lopez Bernal A, Watson SP, Phaneuf S \& Europe-Finner GN 1993 Biochemistry and physiology of preterm labour and delivery. Baillière's Clinical Obstetrics and Gynaecology 7 523-552. (doi:10.1016/S09503552(05)80447-X)

Loverro G, Greco P, Vimercati A, Nicolardi V, Varcaccio-Garofalo G \& Selvaggi L 2001 Maternal complications associated with cesarean section. Journal of Perinatal Medicine 29 322-326. (doi:10.1515/JPM. 2001.046)

Lye SJ 1996 Initiation of parturition. Animal Reproduction Science 42 495-503. (doi:10.1016/0378-4320(96)01529-1)

Lye SJ \& Porter DG 1978 Demonstration that progesterone 'blocks' uterine activity in the ewe in vivo by a direct action on the myometrium. Journal of Reproduction and Fertility 52 87-94. (doi:10.1530/jrf.0. 0520087)

Lye SJ, Ou C-W, Teoh T-G, Erb G, Stevens Y, Casper R, Patel AF \& Challis John RG 1998 The molecular basis of labour and tocolysis. Fetal and Maternal Medicine Review 10 121-136. (doi:10.1017/ S096553959800031X)

Manabe Y, Kinouchi T \& Ohnishi Y 1985 Identification and quantification of highly mutagenic nitroacetoxypyrenes and nitrohydroxypyrenes in diesel-exhaust particles. Mutation Research 158 3-18. (doi:10.1016/ 0165-1218(85)90092-8)

Noble K, Zhang J \& Wray S 2006 Lipid rafts, the sarcoplasmic reticulum and uterine calcium signalling: an integrated approach. Journal of Physiology 570 29-35. (doi:10.1113/jphysiol.2005.098475)

Okamoto T, Schlegel A, Scherer PE \& Lisanti MP 1998 Caveolins, a family of scaffolding proteins for organizing "preassembled signaling complexes" at the plasma membrane. Journal of Biological Chemistry 273 5419-5422. (doi:10.1074/jbc.273.10.5419)

Orsino A, Taylor CV \& Lye SJ 1996 Connexin-26 and connexin-43 are differentially expressed and regulated in the rat myometrium throughout late pregnancy and with the onset of labor. Endocrinology 137 1545-1553. (doi:10.1210/en.137.5.1545)

Osman I, Young A, Ledingham MA, Thomson AJ, Jordan F, Greer IA \& Norman JE 2003 Leukocyte density and pro-inflammatory cytokine expression in human fetal membranes, decidua, cervix and myometrium before and during labour at term. Molecular Human Reproduction 9 41-45. (doi:10.1093/molehr/gag001)

Ou CW, Orsino A \& Lye SJ 1997 Expression of connexin-43 and connexin26 in the rat myometrium during pregnancy and labor is differentially regulated by mechanical and hormonal signals. Endocrinology 138 5398-5407. (doi:10.1210/en.138.12.5398)

Piechota W \& Staszewski A 1992 Reference ranges of lipids and apolipoproteins in pregnancy. European Journal of Obstetrics, Gynecology, and Reproductive Biology 45 27-35. (doi:10.1016/0028-2243(92) 90190-A)

Poore KR, Young IR \& Hirst JJ 1999 Efficacy of the selective prostaglandin synthase type 2 inhibitor nimesulide in blocking basal prostaglandin production and delaying glucocorticoid-induced premature labor in sheep. American Journal of Obstetrics and Gynecology 180 1244-1253. (doi:10.1016/S0002-9378(99)70624-1)

Ramsay JE, Ferrell WR, Crawford L, Wallace AM, Greer IA \& Sattar N 2002 Maternal obesity is associated with dysregulation of metabolic, vascular, and inflammatory pathways. Journal of Clinical Endocrinology and Metabolism 87 4231-4237. (doi:10.1210/jc.2002-020311)

Riley M, Baker P \& Taggart M 2003 Effects of methyl- $\beta$-cyclodextrin on spontaneous and oxytocin-induced contractility of isolated human uterine smooth muscle. Journal of Physiology 522P P64.

Schlegel A, Volonte D, Engelman JA, Galbiati F, Mehta P, Zhang XL, Scherer PE \& Lisanti MP 1998 Crowded little caves: structure and function of caveolae. Cellular Signalling 10 457-463. (doi:10.1016/ S0898-6568(98)00007-2) 
Scott JE, Grigsby PL, Hirst JJ \& Jenkin G 2001 Inhibition of prostaglandin synthesis and its effect on uterine activity during established premature labor in sheep. Journal of the Society for Gynecologic Investigation 8 266-276. (doi:10.1016/S1071-5576(01)00124-1)

Shaul PW \& Anderson RG 1998 Role of plasmalemmal caveolae in signal transduction. American Journal of Physiology 275 L843-L851.

Smith RD, Babiychuk EB, Noble K, Draeger A \& Wray S 2005 Increased cholesterol decreases uterine activity: functional effects of cholesterol alteration in pregnant rat myometrium. American Journal of Physiology. Cell Physiology 288 C982-C988. (doi:10.1152/ajpcell.00120.2004)

Somlyo AP 1985 Excitation-contraction coupling and the ultrastructure of smooth muscle. Circulation Research 57 497-507.

Thomson AJ, Telfer JF, Young A, Campbell S, Stewart CJ, Cameron IT, Greer IA \& Norman JE 1999 Leukocytes infiltrate the myometrium during human parturition: further evidence that labour is an inflammatory process. Human Reproduction 14 229-236. (doi:10.1093/ humrep/14.1.229)

Toescu V, Nuttall SL, Martin U, Nightingale P, Kendall MJ, Brydon P \& Dunne F 2004 Changes in plasma lipids and markers of oxidative stress in normal pregnancy and pregnancies complicated by diabetes. Clinical Science 106 93-98. (doi:10.1042/CS20030175)

Wathes DC \& Porter DG 1982 Effect of uterine distension and oestrogen treatment on gap junction formation in the myometrium of the rat. Journal of Reproduction and Fertility 65 497-505. (doi:10.1530/jrf.0. 0650497)

Wathes DC, Guldenaar SE, Swann RW, Webb R, Porter DG \& Pickering BT 1986 A combined radioimmunoassay and immunocytochemical study of ovarian oxytocin production during the periovulatory period in the ewe. Journal of Reproduction and Fertility 78 167-183. (doi:10.1530/jrf.0.0780167)

Weiss JL, Malone FD, Emig D, Ball RH, Nyberg DA, Comstock CH, Saade G, Eddleman K, Carter SM, Craigo SD et al. 2004 Obesity, obstetric complications and cesarean delivery rate - a population-based screening study. American Journal of Obstetrics and Gynecology 190 1091-1097. (doi:10.1016/j.ajog.2003.09.058)

WHO 2000 Obesity: preventing and managing the global epidemic. Report of a WHO consultation. World Health Organization Technical Report Series 894 1-253.

Willecke K, Eiberger J, Degen J, Eckardt D, Romualdi A, Guldenagel M, Deutsch U \& Sohl G 2002 Structural and functional diversity of connexin genes in the mouse and human genome. Biological Chemistry $\mathbf{3 8 3}$ 725-737. (doi:10.1515/BC.2002.076)

Zhang J, Bricker L, Wray S \& Quenby S 2007 Poor uterine contractility in obese women. BJOG: an International Journal of Obstetrics and Gynaecology 114 343-348. (doi:10.1111/j.1471-0528.2006.01233.x)

Zuo J, Lei ZM, Rao CV, Pietrantoni M \& Cook VD 1994 Differential cyclooxygenase- 1 and -2 gene expression in human myometria from preterm and term deliveries. Journal of Clinical Endocrinology and Metabolism 79 894-899. (doi:10.1210/jc.79.3.894)

Received 7 September 2010

First decision 25 October 2010

Accepted 15 November 2010 